\title{
LANGUAGE AND ANGLICAN CANON LAW - DABBLING BRIEFLY INTO ANOTHER LEGAL WORLD
}

\author{
Bill Atkin*
}

Canon law is a body of rules that govern churches. It has a venerable history and has at times marched in step with the common law. It has a specialised vocabulary - even the word canonmuch of which is derived from Greek. It also has sophisticated legislative systems, which vary from denomination to denomination and from place to place. In the case of the Anglican Church of New Zealand, the system is in part based on the Westminster model but has been modified when thought appropriate, with the result that the language used is partly familiar to the average lawyer but partly not. The exact legal nature of canon law is uncertain and may depend in part on whether the church is the established religion or not. In New Zealand where there is no establishment, a comparison could be made, inter alia, with customary law.

\section{WHAT IS CANON LAW?}

The phrase canon law may not often trip off the tongues of many New Zealand lawyers. It may conjure up the intrigues of the novels of Trollope or the rulings of the Vatican more than the daily grist of legal practice or study. Yet, even in New Zealand, there are many church denominations that are governed by their own sets of rules. While for the Roman Catholic Church there is a single body of canons that apply universally, ${ }^{1}$ most other churches have more locally-based rules. For example, the Presbyterian Church in New Zealand has a Book of Order that applies nationwide and is the result of legislative decisions made by the General Assembly. The Anglican Church, which is the main focus of this note, has several layers of canon law, some of it applicable nationally and some

* Professor of Law, Victoria University of Wellington. Special thanks to my research assistant, David Neild, for his excellent work and to John B Morrison, Chancellor Emeritus of the Anglican Diocese of Wellington, for his comments.

1 Cox writes "[p]erhaps unfortunately for the Anglican Communion, unlike in the Latin Church there is no single body of canons in the Communion": Noel Cox Church and State in the Post-Colonial Era The Anglican Church and the Constitution in New Zealand (Polygraphia, Auckland, 2008) at 46. 
of it created by each of the dioceses that make up the national church. ${ }^{2}$

The New Zealand Anglican Church is an independent entity but is part of the international Anglican Communion. ${ }^{3}$ While there has recently been talk, sparked largely by differences over attitudes to gay and lesbian clergy, of an international covenant ${ }^{4}$ binding on national churches, this is a controversial move that has some way to go before it is agreed to. ${ }^{5}$ Besides, it is hard to see how it can override or render invalid locally enacted canon laws. Its impact will be more at the level of international co-operation.

"Canon law" is defined in one dictionary as "ecclesiastical law", ${ }^{6}$ that is, the law that applies to the church. However, Professor Cox, with good reason, distinguishes between the two. ${ }^{7}$ Canon law is that body of law created through the Church's own internal legislative mechanisms, whereas ecclesiastical law encompasses not only canon law but also the ordinary law of the land that relates to the Church, much of it to do with church property and trusts. ${ }^{8}$ Historically, canon law and the common law were close bedfellows. For example, marriage law was largely canon law ${ }^{9}$ but today canon law is essentially confined in its operation to those who are members of the Church.

\section{SPECIALISED LANGUAGE}

Already we have met some specialised terminology. The word canon itself is derived from the Greek "kanōn" ("rule"). According to the Archbishops' Commission on Canon Law, it also means "a straight rod" or "line": 10

2 Officially the Anglican Church in New Zealand is the Anglican Church in Aotearoa, New Zealand and Polynesia, and, as the name implies, it extends beyond New Zealand to the Pacific countries that make up Polynesia.

3 See Norman Doe Canon Law in the Anglican Communion A Worldwide Perspective (Clarendon Press, Oxford, 1998).

4 The word covenant rather than contract, treaty or law is itself replete with theological overtones that are beyond the concerns of this note.

5 However, the General Synod of the Church of England meeting in London passed a motion relating to the covenant with surprising ease, but this is only one stage in its approval: "Anglican Covenant: Reservations, But the Covenant Moves Forward" Church Times (London, 26 November 2010) at 3.

6 Oxford English Dictionary "Canon 1b" (2010) <www.oed.com>.

7 Cox, above n 1 , at 19

8 See the long list of such New Zealand statutes in Cox, ibid, at 139-140, fn 340.

9 The full history of the relationship between canon law and common law is complex: see for example W Latey The Tide of Divorce (Longman, London, 1970) and E W Kemp An Introduction to Canon Law in the Church of England (Hodder and Stoughton, London, 1957).

10 Archbishops' Commission on Canon Law The Canon Law of the Church of England (SPCK, London, 1947) at 7, cited in Hubert S Box The Principles of Canon Law (Oxford University Press, London, 1949) at 9. 
The word was applied to legislative enactments of the Church's councils, because they aimed at leading the members of the Church in the right way or offered a rule of right conduct or straightened out what had gone amiss in the life of the Church. The word was not only applied to each individual enactment of a council; the sum total of canons was held to make up a body of law governing the internal affairs of the Church, and it was called the Canon Law to distinguish it from Roman Civil Law.

"Canon" is also used to mean the collection of books that form the Bible, or "the canon of scripture"; in other words, the writings that are officially accepted as canonical or the genuine text of scripture (not that there is unanimity on this in the various branches of the Christian church). ${ }^{11}$ Hubert Box cites St Irenaeus speaking of "the canon of truth" received at baptism. ${ }^{12}$ Canonisation is used in relation to the declaration of someone as a saint, that is, a signal of the official genuineness of someone's sainthood. A canon is also a member of a cathedral "chapter", which is the body that rules in the cathedral, although these days only nominally. Along with all these ecclesiastical uses, the word "canon" can of course be used to refer to a body of secular law, even of such things as the canon of Sherlock Holmes stories written by Arthur Conan Doyle (rather than someone else). ${ }^{13}$

The word diocese is used primarily in Catholic, Anglican and Orthodox churches. It is a partly

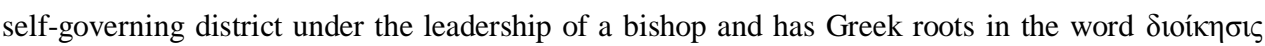

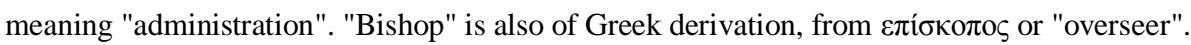

The Greek derivation of these and other words is largely explained by the fact that the New Testament was written in Greek (although drawing on the Aramaic that Jesus used). With the spread of Christianity and its acceptance by the Roman Empire, the language also spread. There was a flood of ideas and vocabulary. According to F E Harrison, writers "of genius" such as Tertullian, Ambrose, Jerome and Augustine of Hippo: ${ }^{14}$

... between them bequeathed to the West an immense legacy of Christian "classics" to set beside the pagan ones. As the tide of barbarism advanced, and literacy came to rest largely with the clergy, this thought and language seeped into every form of literature and written records, secular as well as religious, poetry as well as prose.

11 The pre-New Testament books called by some as The Apocrypha are treated as part of the canon by the Roman Catholic Church but not by Protestant denominations (hence the word apocryphal). The Anglican Church "doth read [the other Books] for example of life and instruction of manners; but yet doth it not apply them to establish any doctrine": Article VI of the Thirty-Nine Articles of Religion as agreed at a convocation of bishops in London 1562.

12 Box, above n 10, at 9.

13 For example, Arthur Conan Doyle The Final Adventures of Sherlock Holmes: Completing the Canon (Warner, London, 1993)

14 F E Harrison Millennium A Latin Reader A D 374-1374 (Oxford University Press, London, 1968) at xx. 
Harrison exemplifies this in greater detail: ${ }^{15}$

New Words (largely Greek) flooded in from the Bible and the evolving life of the Church: eg ecclesia, diaconus, presbyter, episcopus, abba(s) (Hebrew by origin, but already naturalized in the N[ew] T[estament]), monachus (monk) eremita (a man of the desert, hermit), clerus (the clerical order) and its adjective clericus (the sing[ular] gives cleric and clerk, the pl[ural] clergy), elemosine (alms), etc.

Many of these words are of course used in a variety of ecclesiastical contexts but the point for present purposes is that canon law and its language have their origins deeply rooted in two millennia of history. This needs to be borne in mind as we explore a few current issues relating to canon law.

\section{THE LEGAL STATUS OF ANGLICAN CANON LAW IN NEW ZEALAND}

How are we to characterise canon law in 21 st century New Zealand? Is it a set of private rules the same as those that any charity, incorporated society or company may have? Is it like customary law, affecting those who are subject to custom but in a broader sense potentially part of the law of the land? Is it really just a contract, although of considerable complexity? Is it sui generis, something that does not fit into any regular legal categories?

According to Cox, the Church's authority does not depend so much on human laws as on divine law. ${ }^{16}$ He says: ${ }^{17}$

If canon law is seen as simply the set of norms of a human society, then it will change according to social and political pressures and circumstances. If canon law is seen as theological, because it has supernatural sources and aims, then it will be created, understood, and practised in specifically Christian ways.

What, however, is secular law to make of this? While the assistance of God is still quaintly sought at the beginning of each day's sitting of Parliament in language redolent of the Anglican Church's old Book of Common Prayer (1662), New Zealand is certainly no theocracy. Nor is the Church established as it is in England. That is to say, there is no official religion in the country, ${ }^{18}$ nor could one be instituted given contemporary New Zealand's pluralistic and bi-cultural flavour. Despite this, Cox argues that the Church in New Zealand is quasi-established because of the close links between Church and state. Although supported by Doe, ${ }^{19}$ this is a controversial position

15 Ibid, at xxiii.

16 Cox, above n 1 , at 11 .

17 Ibid, at 44.

18 Gregory v Bishop of Waiapu [1975] 1 NZLR 705 (SC) at 708.

19 Norman Doe Canon Law in the Anglican Communion A Worldwide Perspective above n 3 at 14-15. His position is largely based on the control of Parliament over Church activities rather than any benefits that the Church obtains. 
especially if it purports to give the Anglican Church special status over and above other denominations. Moreover, secular law has limited scope to delve into the inner workings of the Church and in particular eschews entering into theological debates. ${ }^{20}$

So it is a little hard to say that canon law in New Zealand has special legal status because it is divine or part of an official State religion. That is a category that secular law cannot make sense of. Yet, to consign canon law merely to contract or the law of charities is to belie its origins and the complex mechanism surrounding its existence, amendment and implementation. Let us first consider the history of Anglican canon law in New Zealand. The key development was the establishment of a constitution, which occurred in 1857 after various debates and contortions. ${ }^{21}$ The constitution was created by what is known as consensual compact, not parliamentary legislation, and in this sense it sat independently of statute. The constitution incorporates a set of fundamental provisions, which are entrenched. Canon law that is not in accordance with these provisions is in a very real sense unconstitutional, just as in most countries other than New Zealand legislation can be declared unconstitutional and therefore be of no effect. Thus, the origins of Anglican canon law in New Zealand are the result of a special kind of social covenant entered into by the church leaders of the day and agreed to as having binding force.

Subsequent history altered the explicit legal basis for canon law. The Church of England Empowering Act (a New Zealand statute using the Church's older name) was passed in 1928, enacted essentially to ensure that the Church's property would be secure, ${ }^{22}$ and it includes the constitution with its fundamental provisions. Canon law now depends in part on statute for its legitimacy, although historically this was not so. It means that a particular provision in canon law may end up being not solely unconstitutional because it breaches the constitution but also void because it breaches the secular law. ${ }^{23}$ There was potential for this to happen in the 1970s when the Anglican Church was one of five churches negotiating to become a united church. In so far as some

20 See the famous "Wee Frees" case where a property dispute resulting from the unification of different churches in Scotland reached the House of Lords and, in the end, was resolved only by legislation: General Assembly of Free Church of Scotland v Overtoun [1904] AC 515 (HL) [Wee Frees]. When the Free Church of Scotland voted to unite with the United Presbyterian Church to form the United Free Church, a very small minority successfully objected and were therefore entitled to hold the Free Church's property "for behoof of" the Church.

21 See W P Morrell The Anglican Church in New Zealand A History (Anglican Church of the Province of New Zealand, Dunedin, 1973) at ch 3.

22 See, for example, the Hon Sir James Allen, moving the second reading in the Legislative Council (where the Bill began its Parliamentary history): (21 August 1928) 218 NZPD 357. Sir James referred to the Wee Frees case, mentioned above n 20.

23 The role of secular law in supervising church activities (for example administrative law and the High Court's inherent powers) is in itself an interesting question beyond the scope of this note. See Cox, above $n$ 1 , at $217-219$. 
of the proposals may have breached the fundamental provisions, parliamentary legislation would have been necessary to legalise the move. In the end, church union failed in a plebiscite and the constitutional questions did not materialise.

What are we to conclude from this brief excursion into the source and authority of canon law? Arguably, while the Anglican Church is a "voluntary association", ${ }^{24}$ its canon law nevertheless has some kind of sui generis juristic standing. Quite possibly the same is true of Roman Catholic canon law, perhaps more so given that the legal basis for it is the authority of another sovereign state, namely the Vatican. Whether there is much practical significance in this conclusion is moot, but, if a comparison is made linguistically with customary law, then we are talking about a body of law that is distinct from the local cricket club, or the rules of a company and, to an extent, exists in its own right.

\section{LEGISLATIVE SYSTEMS}

Another way of viewing canon law is by looking at the mechanisms for creating and amending the law. Here, comparisons with customary law break down, because there are various quite sophisticated sets of procedural rules in relation to Anglican canon law in New Zealand (and elsewhere). In broad terms, the procedures reflect many aspects of the Westminster system of government but with some notable departures. At the national level, General Synod is in effect the

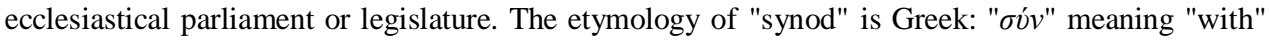

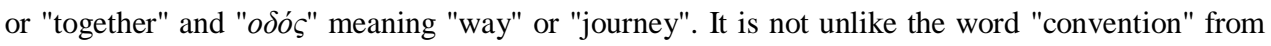
the Latin for "coming together" but synod and synodical tend not to be used outside ecclesiastical contexts. This again underlines the notion that canon law and its accompanying constitutional structures are of a distinct and idiosyncratic nature.

General Synod makes law for the whole of New Zealand and Polynesia. One of the distinctive features about Anglican synodical government is that decisions are made by orders. There are three orders: bishops, clergy and laity, and each order has, in effect, a veto over the other. The decisionmaking process is not done by simple majority but by majorities in each order, that is, if a vote or division is called for on this basis. ${ }^{25}$ This means that there is a system of checks and balances that ensures that synodical government does not on the one hand become over-clericalised or, on the other, dominated by lay people. The subtleties of this are not really comparable to the secular New Zealand parliament but there is a parallel with the distinction between the House of Commons and the House of Lords, and in federations with the composition of a senate, as in the United States, which is designed to ensure that small states are not overwhelmed by large ones.

General Synod in New Zealand has a further complexity, which is also part of the checks and

24 Gregory v Bishop of Waiapu, above n 18.

25 In practice, often passed on a voice vote or show of hands. 
balances. There is a division, distinct from that between orders, between three tikanga: ${ }^{26}$ Māori, Pasifika and Pākehā. Indeed, according to the procedural rules, ${ }^{27}$ a vote according to tikanga, technically a Declaration of Assent by Tikanga, precedes a vote by orders, the latter not occurring if there is a lack of assent. The creation of the three tikanga was part of the Church's own reflection on the implications of the Treaty of Waitangi and the resulting concept of bi-cultural partnership. As already explained, the New Zealand Anglican Church extends into Polynesia, so in effect a tricultural governance model was established. There is no real equivalent in Parliament, despite the existence of the Māori seats.

Other aspects of the legislative process bear more of the hallmarks of the Westminster Parliament. Any enactment, amendment or repeal is commenced by a Bill, which is vetted by a Statutes and Canons Committee, a lesser version of the Parliamentary Counsel Office. One of the additional tasks of this committee is to ensure that any measure is constitutional but it is also instructed "to comply with the principles of plain language drafting." 28 A Bill must then go through four stages: introduction, approval in principle, approval in detail in the Committee of the Whole Synod, and confirmation. These steps mirror the various readings that a Bill receives in Parliament. It is also possible to send a Bill to a specially set up select committee but, unlike parliamentary select committees, these are simply an internal mechanism during sittings of General Synod (every two years) and there is no provision for public or parishioner input.

Just as society has a parliament for nationwide statutes along with procedures at local government level for the creation of by-laws, so the Church has synods for each diocese and a further body of canon law that applies only at diocesan level. Each diocese has its own standing orders and procedures for legislation. In the Wellington Diocese, as an example, the diocesan synod meets once a year, although its current practice is to deal with legislation only every second year. Until recently, legislation was handled by way of vetting by the Revising Committee, ${ }^{29}$ then introduction with three readings. This however was changed in 2007 so that legislation, still subject to the same vetting process, can be passed by a simple resolution. If there are complexities and motions to amend the proposal, the synod can go into committee to consider the detail. The reason for the change was that the system of various readings of legislation was somewhat laborious and frankly unnecessary for a church organisation. It was also thought that the Synod should be spending a lot more of its time on other matters - one major opportunity for debate of an enactment was thought to be enough. The safeguard of voting by orders, discussed above in the context of General Synod, applies but this occurs only rarely when there is a degree of contention. The three

26 Tikanga is Māori for habit, method, custom, practice.

27 Standing Orders of the General Synod/Te Hīnota Whānui, 2008, SO 59.

28 Ibid, SO 83.2(b)(iii).

29 Created under the Diocesan Legislation Revision Canon 2007. 
tikanga model does not apply at this level because the Wellington Diocese is part of Tikanga Pākehā. There is a Tikanga Māori equivalent that covers a similar geographical area.

\section{THE LANGUAGE AND FORM OF CANON LAW IN NEW ZEALAND}

At the same time as introducing the simplified procedure for passing legislation, the Wellington Synod also changed the terminology it uses to refer to legislation. Previously it used the parliamentary language of Bills and Acts, but, to send a signal that Synod was treating the legislative process differently, the language was also changed. The use of the word canon is obviously consistent with usage elsewhere but there are some traps. There is now no equivalent to Bill to refer to a proposed canon or amendment to a canon. The advantage of having the word Bill in relation to secular legislation is that a distinction can be drawn between the original version (and its amended version) and the final enactment. Also, the different layers of canons can lead to confusion: are we dealing with the national canons or the local ones? In an attempt to avoid this, the Wellington canons all begin with the word Diocesan but we cannot be sure that the average clergy or lay person appreciates the subtleties of all this.

Despite the name change, the Wellington canons in form are ironically much closer to parliamentary legislation than General Synod canons. The latter are indeed something of a quagmire to work through. They are divided into seven Titles, each relating to a particular subject-matter. For example, Title B is "OF ORGANISED BODIES IN THE CHURCH" (capital letters are used in the official record and the use of the word of at the start is a curiosity to the 21 st century eye). This Title is divided into 31 canons dealing with different subjects, such as "CANON I"30 "OF THE GENERAL SYNOD/TE HĪNOTA WHĀNUI" (again, all in capital letters). This canon is then divided into six clauses, somewhat anomalously indicated by $\S$, and each clause is then divided into subclauses such as 1.1 with further divisions in to 1.1.1 and even 1.1.10(a), the interpretation clause being $\$ 6$ at the end. This is all very confusing but, if we go to Canon I Title D, we get even more confused for this divides the canon into Parts rather than clauses, such as "PART A OF MAINTENANCE OF STANDARDS OF MINISTRY FOR BISHOPS, MINISTERS AND OFFICE BEARERS", followed by clauses that are sometimes broken down into "10.1" "13.1.5", and so on. The format of General Synod canons makes referencing hard but it also hard to find one's way around the provisions themselves. The content can also be obtuse, with a drafting style more redolent of past times: long sentences, provisos, subject to and so forth.

It is something of a relief to find that the Wellington canons are much more straightforward. There are no titles. Each canon stands on its own two feet and has a clear name. The interpretation provision comes early. Each canon is divided into sections with subsections for each sentence. Some canons, like parliamentary legislation, are divided into parts but the section numbers still run

30 The next canon is Canon II, not Canon 2. 
consecutively. There has been an attempt to use plain English, avoid legislative jargon and include clear headings. The contents are listed at the beginning. There is a canon of general application that sets out, inter alia, rules of construction and common definitions. Interestingly, "Canons" is defined to mean General Synod canons while there is a separate definition for "Diocesan Canon". In summary, the Wellington canons have adopted the current parliamentary drafting style.

One qualification on the positive picture painted of the diocesan canon law is that "legislation" includes the Diocesan Standing Orders and Standing Resolutions. ${ }^{31}$ The former are no problem as they are simply the rules governing the conduct of synod, similar to the Standing Orders of Parliament. However, the Standing Resolutions are a somewhat motley collection of matters to do with organisations, property and various miscellaneous things including a code of conduct and a code of ethics. Their form varies and in places has echoes of General Synod canons. Most of them ought to be in the form of a canon, while some others are very short and anomalous, such as one requiring marriages to be solemnised in a church "except in exceptional circumstances". No indication is given of what may constitute exceptional circumstances. Why are there these Standing Resolutions? One reason might be that they could be passed by a single debate and vote in synod. Now that this same procedure also applies to canons, there may be little reason to retain them as a separate form of legislation.

\section{ONE PARTICULAR CANON}

The longest and one of the most important canons in the Wellington diocese is the Diocesan Parishes Canon 2007. As the diocese is divided into a number of smaller units called parishes (as well as some other units such as chaplaincies), the proper regulation of these units is crucial. A parish is typically led by a vicar, ${ }^{32}$ who is an ordained member of the clergy, two wardens, one appointed by the vicar and the other elected by the lay parishioners, and an annually elected council called a vestry. The latter word is somewhat unusual. It usually refers to the room in a church where robes and vestments are kept and where those participating in services get dressed or vested. The word took on its other meaning because the parish council at various points met in the vestry.

The previous Parishes Act $1992^{33}$ was seen to be in need of revision. One reason was that some parishes were getting too small to afford to pay for a vicar and novel ways of administering the parish were being explored. Other reasons included perceived gaps in the Act. For instance, there was no provision for a roll to determine who was entitled to vote at parish meetings. There were

31 Diocesan Legislation Revision Canon 2007, s 3.

32 The venerable word "vicar" has connections with the legal word "vicarious". Traditionally, the vicar had "the cure of souls" of a parish, in other words a vicarious responsibility for the spiritual lives of parishioners. "Vicar" comes from the Latin "vicarius", meaning "substitute", which in turn comes from "vicis" meaning, inter alia, change, alternation, place or stead. The latter surfaces in the phrase "vice versa".

33 It was an Act because it pre-dated the changes in terminology in 2007, discussed above. 
instances, in the absence of rules, where meetings could be stacked or alternatively where a person with a legitimate interest could be excluded. As a result, a group was established to revise the Act and produce a new version. ${ }^{34}$ The task was much greater than at first imagined and lasted several years. It required quite a degree of consultation and some testing of the waters with synod representatives. The end result was the new Diocesan Parishes Canon 2007 containing 103 sections.

Unusually the canon starts with a Preamble. This is because it was thought that the canon should begin with a theological and aspirational statement to set the right framework for what follows. After that, the canon looks not unlike any other piece of parliamentary legislation, with the initial sections covering the title, commencement, purposes and interpretation. There are then six parts addressing the structure of parishes, the electoral roll, meetings of parishioners, the regulation of the vestry, employment matters and finally property and financial matters.

While some of the provisions relate to concepts that are peculiar to the church, many are not that dissimilar from ones that could apply to any secular organisation. The concept of a parish is peculiar to churches, and added to the provisions found in the previous law are sections dealing with "local shared ministry parishes", where there is no vicar and the day-to-day life of the parish is managed on more of a team basis. The new sections dealing with the electoral roll were not straightforward to decide on, especially the criteria for eligibility to be on the roll. As a sign of the times, many parishioners do not live within the parish boundaries and they may not officially be Anglicans. How can the law reflect these realities without leaving the door open to people who are indifferent or hostile to the church signing up and voting in parish elections? Section 26 endeavours to strike the balance as follows:

A person is entitled to be enrolled on the parish electoral roll if the person is -

(a) is baptised; and

(b) whether resident in the parish or not has, for at least 4 months within the previous 2 years, participated in the worship and life of the parish or is known by the vicar and wardens to be qualified for enrolment; and

(c) signs the declaration set out in subsection (2).

The form of declaration is "I ... declare that I have been baptised and wish to be on the electoral roll of the [name] parish." The declaration was originally proposed to include a provision that electors assented to the laws of the Anglican Church but this was watered down by a vote in synod. The form that now exists appears to achieve very little as it is little more than the expression of a wish to be on the roll. One could be forgiven for thinking that it is largely redundant. Criterion (b) also has difficulties. It is designed to cover the situation where people come from outside parish

34 The ad hoc group consisted of four lawyers (including the Chancellor, a member of the Parliamentary Counsel Office and the author), one clergyperson and one diocesan administrator. 
boundaries but how is the precise condition of four months to be monitored? In other words, who is doing the counting? The phrase "is known ... to be qualified ..." has the opposite problem because it lacks precision. What are the qualifications being referred to? The provision appears to be question-begging.

There are many other sections in the canon that could be explored but enough has been discussed to indicate that the process of law reform and the interpretation of the ensuing legislation can be fraught in much the same way as parliamentary legislation can be. The language used is crucial. On occasions this leaves questions to be answered by the Chancellor, the official legal adviser of the diocese. ${ }^{35}$

\section{CONCLUSION}

This article provides a brief excursus into the discrete area of canon law. In the New Zealand Anglican Church for instance, the legislation-making processes draw in part on the British parliamentary model and its terminology, but the language of canon law contains unique concepts, mostly inherited from the past, that make little sense in other contexts. Canon law has a distinct tongue and a long and venerable tradition.

Canon law has its own legitimacy, but its application is limited because it applies only within the framework of the Church. In this respect, there are points of comparison with customary law ${ }^{36}$ but also many points of difference, not least because customary title and concepts may have wider implications and because canon law is shaped by a sophisticated body of its own well-defined rules.

Although canon law was once influential in forming the common law, the latter has long ago moved away from any direct connection with canon law, thus securing its credentials in a (relativist post-modern) land of the 21 st century. Interestingly, we now see pressures for the accommodation of Māori customary law. In a sense we are coming full circle but we shall not end up in the place where we started. Whether there is a lesson to be learnt from the relationship between canon law and common law for future partnerships between Māori and Parliamentary law is beyond the scope of this note. What can be seen, however, is that canon law has retained its distinctiveness and richness partly because its terms are linked, through its etymology, with its past. When considering the use of customary concepts in today's legal landscape, the added value of non-English words

35 The authority for the appointment of the Chancellor is Title D of the General Synod Canons: Canon IV of Chancellors and Legal Advisors. Interestingly, it is said that the Chancellor "shall exercise such traditional roles as are part of the office of Chancellor in this Church", a very fine piece of writing that conveys virtually no information. The Chancellor must be a barrister or solicitor of the High Court of seven years standing (or equivalent in Polynesia).

36 Custom in fact has itself a long history in the context of ecclesiastical law. See for example Hubert S Box, above $\mathrm{n} 10$, at ch 5 . 
should not be overlooked. They tell us where our laws and tikanga have come from. This is certainly true of contemporary canon law in New Zealand. 